\title{
KOMBINASI PENGEMASAN VAKUM DAN KETEBALAN KEMASAN UNTUK MEMPERPANJANG UMUR SIMPAN TEMPE
}

\section{COMBINATION OF VACUUM PACKAGING AND PACKING THICKNESS TO PROLONG THE SHELF LIFE OF TEMPE}

\author{
Fahrur Razie ${ }^{1)}$, Lina Widawati ${ }^{2)}$ \\ ${ }^{1)}$ Badan Pelaksana Penyuluhan Pertanian Perikanan dan Kehutanan (BP4K) Kabupaten \\ Bengkulu Selatan \\ ${ }^{2)}$ Proram Studi Teknologi Pertanian, Fakultas Pertanian, Universitas Dehasen Bengkulu \\ Email : lina84id@gmail.com
}

\begin{abstract}
ABSTRAK
Tempe mudah rusak tanpa perlakuan khusus. Tujuan dari penelitian ini adalah untuk mengetahui berapa hari masa simpan tempe kedelai yang dikemas dengan kemasan sekunder plastik PP dengan metode vakum dan non vakum yang masing-masing disimpan pada suhu ruang.

Perlakuan yang digunakan dalam penelitian ini yaitu $\mathrm{P}_{1} \mathrm{~T}_{1}$ (Pengemasan non vakum tebal kemasan $0.05 \mathrm{~mm}$ ), $\mathrm{P}_{1} \mathrm{~T}_{2}$ (Pengemasan non vakum tebal kemasan $0.06 \mathrm{~mm}$ ), $\mathrm{P}_{2} \mathrm{~T}_{1}$ (Pengemasan vakum disimpan tebal kemasan $0.05 \mathrm{~mm}$ ), serta $\mathrm{P}_{2} \mathrm{~T}_{2}$ (Pengemasan vakum tebal kemasan $0.06 \mathrm{~mm}$ ). Parameter pengamatan yang digunakan dalam penelitian ini adalah uji kadar protein, uji organoleptik. Pengolahan data yang digunakan menggunakan rancangan acak lengkap.

Hasil penelitian menunjukan bahwa penurunan kadar protein tempe yang paling lambat dan masih diatas standar SNI (kadar protein tempe minimal 16\%) yaitu tempe dengan perlakuan vakum dan kemasan sekunder plastik PP $0.06 \mathrm{~mm}$. Umur simpan dari perlakuan vakum kemasan sekunder plastik PP $0.06 \mathrm{~mm}$ maksimal bertahan 4 hari..
\end{abstract}

Kata Kunci : tempe, jenis kemasan, umur simpan, vakum

\section{ABSTRACT}

Tempe is easy to destroy without special treatment. The objective of this research is to know how many day a shelf life tempe with tidiness of plastic PP with vacuum method and non vacuum which each kept at room temperature.

Treatment which is used in this research that is $P_{1} T_{1}$ (non vacuum packaging thick $0.05 \mathrm{~mm}$ ), $P_{1} T_{2}$ ( non vacuum packaging thick 0.06mm), $P_{2} T_{1}$ (Vacuum Packaging thicks $0.05 \mathrm{~mm}$ ), and also $P_{2} T_{2}$ (Vacuum Packaging thick $0.06 \mathrm{~mm}$ ). Parameter of observation which used in this research is protein rate test, sensoric test. Data-Processing which used use complete random device.

Result of research is decrease in proteint content of tempe the slowest and still above the sni standard (tempe protein content minimal $16 \%$ ) are tempe with vacuum treatment and plastic secondary packaging PP $0.06 \mathrm{~mm}$, maximum survival 4 days..

Keyword : tempe, type of packaging, shelf life, vacuum 


\section{PENDAHULUAN}

Tempe kedelai adalah makanan hasil fermentasi kedelai rebus dengan jamur Rhizopus. Kedelai saling terikat oleh miselia jamur membentuk padatan yang kompak berwarna putih selama fermentasi. Kandungan proteinnya cukup tinggi serta harganya pun terjangkau sehingga menjadi salah satu produk pangan yang digemari masyarakat Indonesia. Konsumsi tempe rata-rata per orang per tahun di Indonesia saat ini diperkirakan mencapai sekitar $6,45 \mathrm{~kg}$ (BSN, 2012).

Sebagai negara produsen tempe kedelai terbesar di dunia dan menjadi pasar kedelai terbesar di Asia, $50 \%$ konsumsi kedelai Indonesia dijadikan untuk memproduksi tempe, $40 \%$ tahu, dan $10 \%$ dalam bentuk produk lain (seperti tauco, kecap, dan lain-lain). Saat ini, di Indonesia terdapat sekitar 81 ribu usaha pembuatan tempe kedelai yang memproduksi 2,4 juta ton tempe per tahun (BSN, 2012).

Walaupun potensi produksi yang tinggi dimiliki, tetapi tempe kedelai sampai ke konsumen dengan kualitas yang sudah menurun. Hal ini disebabkan oleh sebaran penduduk yang tidak merata dan jarak yang cukup jauh antara konsumen dengan produsen. Permasalahan utama yang dihadapi adalah umur pakai dan umur simpan tempe hanya kurang dari 48 jam. Lebih dari waktu tersebut jamur Rhizopus pada tempe akan mati dan akan tumbuh jamur lain serta bakteri yang dapat merombak protein dalam tempe sehingga menyebabkan bau tidak enak (Ratnawati, 2008).

Salah satu cara untuk mengurangi laju kerusakan produk pangan selama penyimpanan dan transportasi dapat dilakukan dengan teknologi pengemasan metode vakum. Pengemasan metode vakum adalah pengemasan dimana udara dalam bahan pangan dikurangi sehingga laju respirasi dan metabolismenya dapat dikurangi dengan tujuan memperpanjang umur pakai dan umur simpan produk. Pengemasan dengan ketebalan plastik yang berbeda diyakini akan berpengaruh pada umur simpan. Oleh karena itu peneliti tertarik untuk meneliti apakah teknologi pengemasan dengan metode vakum bisa diaplikasikan pada tempe.

\section{METODE PENELITIAN}

\section{Bahan}

Bahan-bahan yang akan digunakan dalam penelitian adalah (a) tempe kedelai, merupakan bahan utama dalam penelitian ini. Tempe kedelai diperoleh dari "Usaha Tahu Tempe" Jalan Trip Kastalani Bengkulu Selatan sesuai dengan jumlah sampel yang dibutuhkan; (b) plastik PP dengan ketebalan $0,05 \mathrm{~mm}$ dan $0,06 \mathrm{~mm}$ sebagai kemasan sekunder; (c) bahan 
analisis kadar protein metode kjeldahl terdiri dari kalium sulfat 7,5 g, raksa (II) oksida $0,35 \mathrm{~g}$, asam sulfat pekat $15 \mathrm{ml}$, aquadest $100 \mathrm{ml}$, lempeng $\mathrm{Zn}$, kalium sulfat 4\% (dalam air) $15 \mathrm{ml}$, natrium hidroksida $50 \%$ sebanyak $50 \mathrm{ml}$, larutan baku asam klorida $0,1 \mathrm{~N}$ sebanyak $50 \mathrm{ml}$, indikator merah metil $0,1 \% \mathrm{~b} / \mathrm{v}$ (dalam etanol 95\%) 5 tetes.

\section{Alat}

Alat-alat yang akan digunakan dalam penelitian adalah (a) para-para atau kisi-kisi, terbuat dari bambu atau kayu yang dibelah, yang berfungsi sebagai alas sampel. Jumlahnya disesuaikan dengan sampel yang akan dianalisis; (b) vacuum sealer (merek Maksipack, tipe DZ-280A), merupakan alat yang digunakan untuk mengeluarkan udara dalam dalam suatu kemasan sekaligus merekatkan kemasan plastik tersebut; (c) alat analisis kadar protein metode kjeldahl, terdiri dari neraca analitik, labu kjeldahl, kompor pemanas, lemari asam, lemari es, labu erlenmeyer, alat tetes, stopwatch; (d) alat analisis umur simpan metode konvensional, terdiri dari pisau, tatakan potong, piring kecil, spidol dan kertas borang.

\section{Cara Penelitian}

Tahap persiapan
Tempe umur 42 jam dari fermentasi dimasukkan ke dalam plastik kemasan sekunder PP 0,05 mm dan 0,06 mm. Dilanjutkan dengan pemakuman sampel sampai dipastikan tidak ada udara didalamnya, kemudian direkatkan. Disiapkan juga sampel tempe tanpa perlakuan vakum dan tanpa kemasan sekunder sebagai pembanding.

\section{Tahap Analisis}

Analisis kadar protein tempe kedelai vakum dan nonvakum akan dilakukan setiap hari sampai dengan hari ke-n dimana kadar protein sampel dibawah standar yaitu 16.

\section{Perlakuan Penelitian}

Sampel tempe yang akan dianalisis diberikan kode sebagai berikut :

$\mathrm{K}=$ Tanpa pengemasan sekunder dan pengosongan udara (kontrol)

$\mathrm{P}_{1}=$ Menggunakan pengemasan sekunder dan pengosongan udara,

$\mathrm{P}_{2}=$ Menggunakan pengemasan sekunder dan tanpa pengosongan udara, $\mathrm{T}_{1}=$ Plastik PP ketebalan 0,05 mm, $\mathrm{T}_{2}=$ Plastik PP ketebalan 0,06 $\mathrm{mm}$.

Sehingga total sampel adalah 5 jenis, yaitu $\mathrm{K}, \mathrm{P}_{1} \mathrm{~T}_{1}, \mathrm{P}_{1} \mathrm{~T}_{2}, \mathrm{P}_{2} \mathrm{~T}_{1}, \mathrm{P}_{2} \mathrm{~T}_{2}$.

Hal-hal yang perlu diperhatikan dalam pembuatan sampel adalah sebagai berikut:

a. Tempe yang akan diberi perlakuan vakum merupakan tempe yang 
pertumbuhan miselianya optimal, dimana secara visual seluruh bagian permukaan tempe berwarna putih. Bila perlakuan vakum diberikan pada tempe yang miselianya masih dalam tahap pertumbuhan, maka kedelai pada permukaan tempe tetap terlihat dan tempe akan berair.

b. Kemasan sampel tempe vakum harus dipastikan direkatkan dengan sempurna, bila terdapat bagian yang terbuka maka akan memungkinkan udara dari luar masuk ke dalam kemasan.

c. Tempe sampel vakum dan nonvakum diletakan diatas para-para atau kisikisi yang terbuat dari kayu atau bambu dan disimpan dalam suhu ruang. Fungsinya untuk mengurangi timbulnya embun dalam kemasan.

\section{Analisis Penelitian}

Analisis penelitian kadar protein sampel tempe vakum dan nonvakum menggunakan metode kjeldahl makro. Hal ini karena bahan atau sampel yang digunakan sukar homogen dan massanya lebih dari $1 \mathrm{~g}$ dan juga sesuai dengan ketersediaan alat yang ada. Metode kjeldahl merupakan metode pengukuran kadar protein dengan mengetahui persentase $\mathrm{N}_{2}$ yang menyusun protein dalam suatu bahan. Untuk mengetahui kadar proteinnya diperoleh dengan mengalikan persentase $\mathrm{N}_{2}$ dengan nilai faktor konversi yaitu 6,25. Analisis dilakukan setiap hari mulai hari ke-0 hingga hari ke-n dimana kadar protein sampel sudah dibawah $16 \%$.

Untuk menganalisis umur simpan tempe kedelai menggunakan metode konvensional yaitu uji sensoris untuk mengetahui tingkat penerimaan konsumen terhadap warna, aroma dan tekstur dengan jumlah panelis agak terlatih sebanyak 20 orang. Analisis dilakukan setiap hari mulai hari ke-0 hingga hari ke-n dimana sampel sudah tidak diterima lagi oleh konsumen.

\section{Rancangan Percobaan}

Data dari penelitian kadar protein dan sensoris diolah menggunakan Rancangan Acak Lengkap (RAL). Hasil pengolahan data dari kedua pengujian di atas akan disajikan dalam Tabel Anova.

\section{HASIL DAN PEMBAHASAN}

\section{Kadar Protein Tempe}

Tempe memiliki bermacammacam kandungan gizi. Kandungan gizi terbanyak terdapat pada protein. Dari berbagai skala produksi maupun dari pengulangan produksi menghasilkan tempe dengan kadar protein yang berbeda, maka ditetapkan standar minimal kadar protein tempe yang diterima konsumen adalah 16\% (BSN, 2012). 
Tempe yang diproduksi mengalami penurunan kadar protein dari waktu ke waktu. Perubahan mutu gizi selama penyimpanan terutama disebabkan oleh aktivitas enzim dan mikroorganisme sehingga tidak layak lagi dikonsumsi. Aktivitas mikroorganisme selama penyimpanan sangat dipengaruhi antara lain oleh suhu dan kandungan oksigen (Ratnawati, 2008). Kandungan protein tempe selama penyimpanan dapat dilihat pada Tabel 1 .

Berdasarkan Tabel 1 bahwa pada hari ke-0 terdapat notasi yang berbeda disetiap kadar protein perlakuan. Hal ini menunjukan bahwa pada hari ke-0 setiap pelakuan memiliki pengaruh yang nyata terhadap kadar protein. Idealnya pada hari ke-0 kadar protein disetiap perlakuan mesti sama, karena sumber dan waktu pengambilan serta keseragaman bahan yang dijadikan sampel adalah sama.

Pada hari ke-0 saat pembuatan sampel dinyatakan selesai dan pengukuran kadar protein dimulai memang terdapat jeda waktu yaitu 2.5 - 3 jam. Dalam selang waktu tersebut kondisi tempe dengan perlakuan kemasan non vakum mulai ada bintik-bintik air menyerupai embun yang terdapat pada permukaan kemasan plastik bagian dalam. Kondisi ini menunjukan bahwa pada perlakuan tersebut terjadi proses oksidasi dengan memanfaatkan oksigen yang tersisa dalam kemasan, menghasilkan karbon dioksida dan air yang kemudian terjebak di dalam kemasan. Hal ini juga didukung oleh bentuk kemasan sampel perlakuan non vakum pada hari ke-4 yang menggembung, yang menunjukan adanya gas hasil oksidasi. Karbon dioksida dan air yang terjebak membuat suhu dan kelembaban meningkat. Peningkatan suhu dan kelembaban ini tidak sesuai dengan lingkungan yang ditoleransi dalam proses fermentasi tempe. Jika suhu dan kelembaban lebih tinggi dari kondisi ideal maka fermentasi tempe akan berhenti. Ini sesuai dengan pendapat Hidayat (2008) yang menyatakan bahwa lingkungan pendukung yang sesuai dengan fermentasi tempe terdiri dari suhu $30^{\circ} \mathrm{C}$, $\mathrm{pH}$ awal 6.8, kelembaban nisbi 70-80\%.

Air yang terdapat pada kemasan non vakum bagian permukaan dalam membuat tempe lebih basah, dimana diketahui jika air meningkat akan berkolerasi dengan peningkatan kadar air dan aktifitas air $\left(a_{w}\right)$. Menurut Suliantari et.al., (1990) kadar air tempe berkisar $61 \%$ dan nilai $\mathrm{a}_{\mathrm{w}}$ tempe $<0.95-0.99$, jika lebih dari nilai tersebut maka fermentasi tempe akan berhenti. Perlakuan non vakum hari ke-0 saat dianalisis kadar protein nilai $\mathrm{a}_{\mathrm{w}}$ tempe $>1$, diindikasikan dengan tempe yang basah. Tempe yang basah memungkinkan proteinnya dirusak oleh mikroba patogen. 
Tabel 1 Kandungan Protein Tempe Selama Penyimpanan (\%)

\begin{tabular}{lcccccc}
\hline \hline & \multicolumn{5}{c}{ Perlakuan } & \multicolumn{5}{c}{ Hari } \\
\hline Kemasan & Tebal Kemasan $(\mathrm{mm})$ & 0 & 1 & 2 & 3 & 4 \\
\hline Non & 0.05 & $15.65^{\mathrm{ab}}$ & $15.54^{\mathrm{ab}}$ & $15.54^{\mathrm{ab}}$ & $15.22^{\mathrm{a}}$ & $15.19^{\mathrm{a}}$ \\
\cline { 2 - 7 } vakum & 0.06 & $15.21^{\mathrm{a}}$ & $14.98^{\mathrm{a}}$ & $14.98^{\mathrm{a}}$ & $14.60^{\mathrm{a}}$ & $14.54^{\mathrm{a}}$ \\
\hline \multirow{2}{*}{ Vakum } & 0.05 & $17.60^{\mathrm{cd}}$ & $17.59^{\mathrm{cd}}$ & $17.59^{\mathrm{cd}}$ & $16.99^{\mathrm{c}}$ & $16.97^{\mathrm{c}}$ \\
\cline { 2 - 7 } & 0.06 & $17.89^{\mathrm{d}}$ & $17.89^{\mathrm{d}}$ & $17.67^{\mathrm{cd}}$ & $17.15^{\mathrm{c}}$ & $17.13^{\mathrm{c}}$ \\
\hline Kontrol & & $19.2^{\mathrm{e}}$ & $19.21^{\mathrm{e}}$ & $19.07^{\mathrm{e}}$ & $16.76^{\mathrm{c}}$ & $15.23^{\mathrm{a}}$ \\
\hline \hline
\end{tabular}

Keterangan : Data diolah mengggunakan uji statistik $\alpha=0,05$ dan uji Duncan

Penurunan kadar protein tempe perlakuan non vakum pada hari ke-0 disebabkan oleh mikroorganisme yang merusak protein dan kurang sterilnya kemasan. Umumnya mikroorganisme yang menyebabkan kerusakan protein tempe adalah Escherichia coli, bakteri jenis Pseudomonas dan Leuconostoc mesenteroides (Dwidjosepoetro, 1981).

Penurunan kadar protein perlakuan vakum pada hari ke-0 disebabkan oleh proses kompresi kemasan terhadap tempe. Proses kompresi terjadi karena daya hisap mesin terhadap kemasan, sehingga terjadi penyimpangan tempe dari mutu awalnya. Menurut Susiwi (2009), Penyimpangan suatu produk dari mutu awalnya disebut deteriorasi. Produk pangan mengalami deteriorasi segera setelah diproduksi. Reaksi deteriorasi dimulai dengan persentuhan produk dengan udara, oksigen, uap air, cahaya, mikroorganisme, atau akibat perubahan suhu. Reaksi ini dapat pula diawali oleh hentakan mekanis seperti vibrasi, kompresi, dan abrasi. Reaksi deteriorasi akan memicu reaksi di dalam produk berupa reaksi kimia, reaksi enzimatis atau proses fisik yaitu penyerapan uap air atau gas dari sekelilingnya. Hal ini menyebabkan perubahan terhadap produk meliputi perubahan tekstur, flavor, warna, penampakan fisik, nilai gizi, maupun mikrobiologis.

Hasil analisis perlakuan pengemasan sekunder vakum dengan kemasan yang berbeda pada $\alpha=0.05$ menunjukan bahwa kadar protein tempe di hari ke-4 masih diatas standar dan tidak berbeda nyata dan dapat dilihat secara keseluruhan terjadi trend penurunan kadar protein pada setiap perlakuan. 


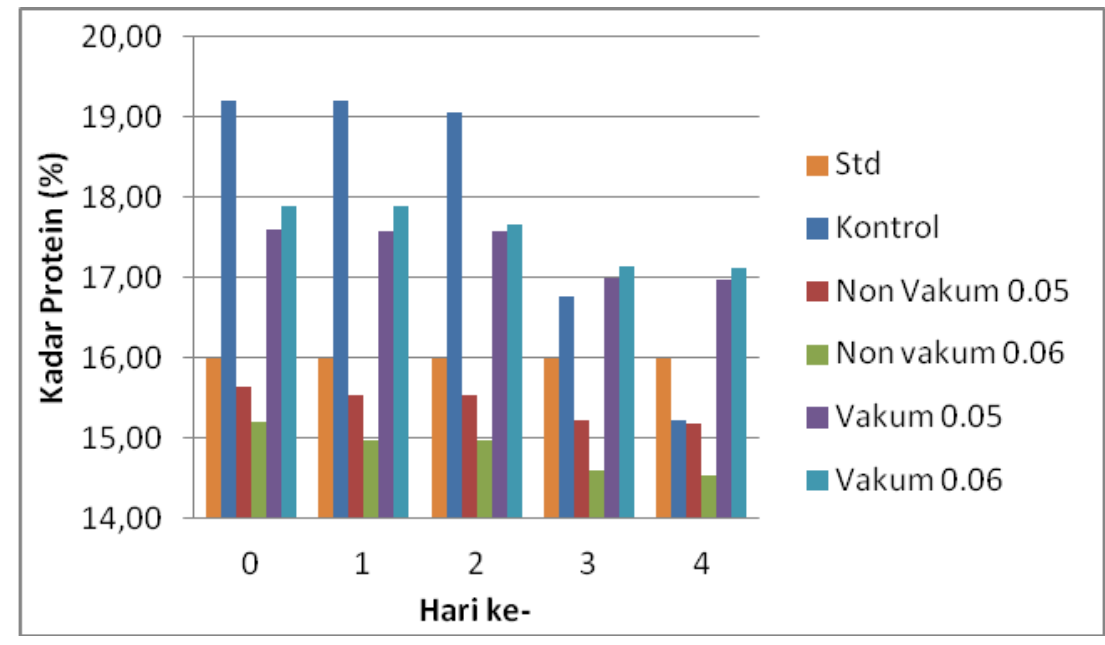

Gambar 1. Laju Penurunan Protein

Pada Gambar 1, kemasan dengan ketebalan berbeda pada perlakuan memberikan pengaruh terhadap nilai kadar protein, walaupun terdapat selisih nilai namun masih dianggap sama. Pada perlakuan non vakum kadar protein tempe kemasan 0.05 lebih tinggi dibandingkan kadar protein kemasan 0.06. Hal ini disebabkan permeabilitas kemasan 0.05 lebih tinggi dibandingkan kemasan 0.06 dimana karbon dioksida yang terbentuk di dalam kemasan lebih banyak keluar dibandingkan kemasan 0.06. Menurut Muslikhah (2013), untuk plastik kemasan PP lebih permeable terhadap karbon dioksida daripada oksigen dan semakin tebal kemasan nilai permeabilitasnya semakin rendah. Pada perlakuan non vakum kemasan 0.05, arah permeable menjadi keluar kemasan karena tekanan karbon dioksida di dalam kemasan lebih tinggi dibandingkan tekanan gas di luar kemasan. Karena jumlah karbon dioksida di dalam kemasan 0.05 lebih rendah dibandingkan kemasan 0.06 maka pada kemasan 0.05 asam amino yang diurai oleh mikroorganisme menjadi lebih sedikit daripada kemasan 0.06 , sehingga kadar protein pada kemasan 0.05 lebih tinggi dibandingkan kemasan 0.06.

Pada perlakuan vakum, kadar protein kemasan 0.06 lebih tinggi dibandingkan dengan kadar protein kemasan 0.05. Hal ini disebabkan tekanan karbon dioksida di luar kemasan lebih rapat daripada di dalam kemasan, sehingga arah permeable karbon dioksida masuk ke dalam kemasan. Karena permeabilitas kemasan 0.05 lebih tinggi daripada kemasan 0.06 maka pada perlakuan vakum kemasan 0.05 karbon dioksida lebih banyak daripada kemasan 0.06, sehingga pada perlakuan vakum kemasan 0.05 asam amino yang dapat 
diurai lebih banyak daripada perlakuan vakum 0.06 , dan dapat dikatakan kadar protein yang tersisa pada perlakuan vakum kemasan 0.05 lebih rendah daripada kemasan 0.06 .

Prosedur penetapan awal (hari ke0) perlakuan pengemasan vakum tidak tepat jika dilakukan di sekitar 42 jam setelah fermentasi, karena di waktu tersebut tempe masih mengalami proses fermentasi walaupun sedikit, lebih optimal dilakukan pada 66 jam setelah fermentasi dimana kadar protein tempe pada titik maksimum.

\section{Sensoris Warna Tempe}

Tempe memiliki warna putih dari hasil pertumbuhan miselium pada tempe. Miselium kapang tumbuh menyelimuti permukaan tempe sehingga tempe tampak putih dan kompak. Pengamatan warna tempe dilakukan oleh panelis dari hari ke0 sampai ke-4 yang hasilnya direpresentasikan melalui skoring data. Hasil rata-rata pengujian warna selama penyimpanan dapat dilihat pada Tabel 2.

Pada Tabel 2 dan Gambar 2 bahwa selama penyimpanan perlakuan tempe menunjukkan pengaruh yang nyata terhadap warna tempe dan trend warna tempe mengalami penurunan.

Pada perlakuan tempe kemasan non vakum perubahan warna lebih cepat dibandingkan dengan perlakuan tempe kemasan vakum dan kontrol. Pada tempe kemasan non vakum asam amino diurai menjadi asam asetat yang dilakukan bakteri asetogenik. Selanjutnya oleh bakteri metanogen, asam asetat diurai menjadi metan, air, karbon dioksida dan amonia. Disamping itu juga menurut Suliantari dan Winiati (1990), perubahan warna disebabkan oleh bakteri Leuconostoc mesenteroides yang mengubah karbohidrat dalam tempe menjadi asam asetat dan berlendir, yang membuat tingkat keasaman bertambah. Seiring dengan peningkatan karbon dioksida, keasaman dan air menyebabkan miselium kapang menjadi mati, sehingga terjadi perubahan warna. Menurut Syarief et al., (1999), Tingkat kecerahan warna tempe berkurang akibat adanya kerusakan struktur miselium kapang yang memberikan warna putih pada tempe. Penurunan perubahan warna juga terjadi akibat degradasi yang terjadi pada miselium kapang yang membentuk matriks dengan protein.

Perlakuan tempe kemasan non vakum 0.05 nilai warna lebih bertahan dibandingkan dengan perlakuan tempe kemasan non vakum 0.06, karena pada kemasan non vakum 0.05 ketersediaan karbon dioksida lebih sedikit dibandingkan kemasan non vakum 0.06, sehingga pada kemasan 0.05 perubahan warna karena pembusukan protein lebih 
lambat dibandingkan dengan kemasan 0.06.

Tabel 2 Uji Sensoris Warna Tempe Selama Penyimpanan

\begin{tabular}{lcccccc}
\hline \hline & \multicolumn{2}{l}{ Perlakuan } & \multicolumn{4}{l}{ Nilai rata-rata panelis pada hari ke- } \\
\hline \multirow{2}{*}{ Kemasan } & Tebal Kemasan (mm) & 0 & 1 & 2 & 3 & 4 \\
\hline Non & 0.05 & $4.00^{\mathrm{e}}$ & $1.55^{\mathrm{a}}$ & $1.50^{\mathrm{a}}$ & $1.45^{\mathrm{a}}$ & $1.10^{\mathrm{a}}$ \\
\cline { 2 - 7 } vakum & 0.06 & $4.00^{\mathrm{e}}$ & $1.60^{\mathrm{a}}$ & $1.45^{\mathrm{a}}$ & $1.25^{\mathrm{a}}$ & $1.05^{\mathrm{a}}$ \\
\hline \multirow{2}{*}{ Vakum } & 0.05 & $4.00^{\mathrm{e}}$ & $3.40^{\mathrm{e}}$ & $3.00^{\mathrm{c}}$ & $2.90^{\mathrm{c}}$ & $2.45^{\mathrm{ab}}$ \\
\cline { 2 - 7 } & 0.06 & $4.00^{\mathrm{e}}$ & $3.55^{\mathrm{e}}$ & $3.00^{\mathrm{c}}$ & $3.00^{\mathrm{c}}$ & $2.70^{\mathrm{c}}$ \\
\hline Kontrol & & $4.00^{\mathrm{e}}$ & $3.80^{\mathrm{e}}$ & $3.05^{\mathrm{c}}$ & $2.00^{\mathrm{ab}}$ & $2.00^{\mathrm{ab}}$ \\
\hline \hline
\end{tabular}

Keterangan : $\quad$ Data diolah menggunakan uji statistik $\alpha=0.05$ dan uji Duncan Skoring : (4) Putih; (3) Putih kekuningan; (2) Kuning; (1) Kuning kehitaman

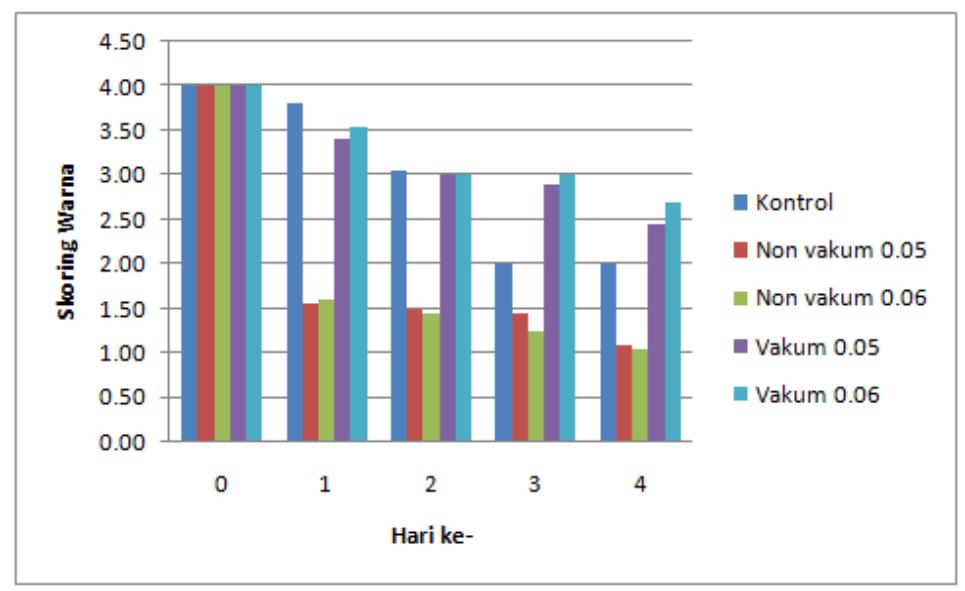

Gambar 2 Penurunan Warna Tempe Selama Penyimpanan

\section{Sensoris Tekstur Tempe}

Tekstur atau kekerasan adalah parameter kekerasan dan kenampakan pada tempe yang dihasilkan dari pengukuran alat maupun penggunaan indera peraba. Tujuan pengukuran dari tekstur atau kekerasan tempe untuk mengetahui pengaruh oksigen terhadap tingkat tekstur atau kekerasan pada tempe selama penyimpanan. Tekstur merupakan salah satu atribut mutu pangan yang penting. Tekstur dapat didefinisikan sebagai kelompok karakteristik fisik yang disebabkan oleh struktur bahan pangan. Uji sensoris tekstur tempe dapat dilihat pada Tabel 3 dan Gambar 3. 
Tabel 3 Uji Sensoris Tekstur Tempe Selama Penyimpanan

\begin{tabular}{lcccccc}
\hline & \multicolumn{2}{c}{ Perlakuan } & \multicolumn{5}{c}{ Nilai rata-rata panelis pada hari ke- } \\
\hline Kemasan & Tebal Kemasan (mm) & 0 & 1 & 2 & 3 & 4 \\
\hline \multirow{2}{*}{ Non vakum } & 0.05 & $4.00^{\mathrm{e}}$ & $1.90^{\mathrm{a}}$ & $1.60^{\mathrm{a}}$ & $1.05^{\mathrm{a}}$ & $1.15^{\mathrm{a}}$ \\
\cline { 2 - 7 } & 0.06 & $4.00^{\mathrm{e}}$ & $1.85^{\mathrm{a}}$ & $1.35^{\mathrm{a}}$ & $1.35^{\mathrm{a}}$ & $1.20^{\mathrm{a}}$ \\
\hline \multirow{2}{*}{ Vakum } & 0.05 & $4.00^{\mathrm{e}}$ & $3.65^{\mathrm{e}}$ & $3.00^{\mathrm{c}}$ & $3.00^{\mathrm{c}}$ & $2.05^{\mathrm{ab}}$ \\
\cline { 2 - 7 } & 0.06 & $4.00^{\mathrm{e}}$ & $3.55^{\mathrm{e}}$ & $3.05^{\mathrm{c}}$ & $2.95^{\mathrm{c}}$ & $2.80^{\mathrm{c}}$ \\
\hline Kontrol & & $4.00^{\mathrm{e}}$ & $3.75^{\mathrm{e}}$ & $2.85^{\mathrm{c}}$ & $2.30^{\mathrm{ab}}$ & $2.05^{\mathrm{ab}}$ \\
\hline
\end{tabular}

Keterangan : $\quad$ Data diolah menggunakan uji statistik $\alpha=0.05$ dan uji Duncan Skoring : (4) Normal; (3) Agak lunak; (2) Lunak; (1) Lunak lengket

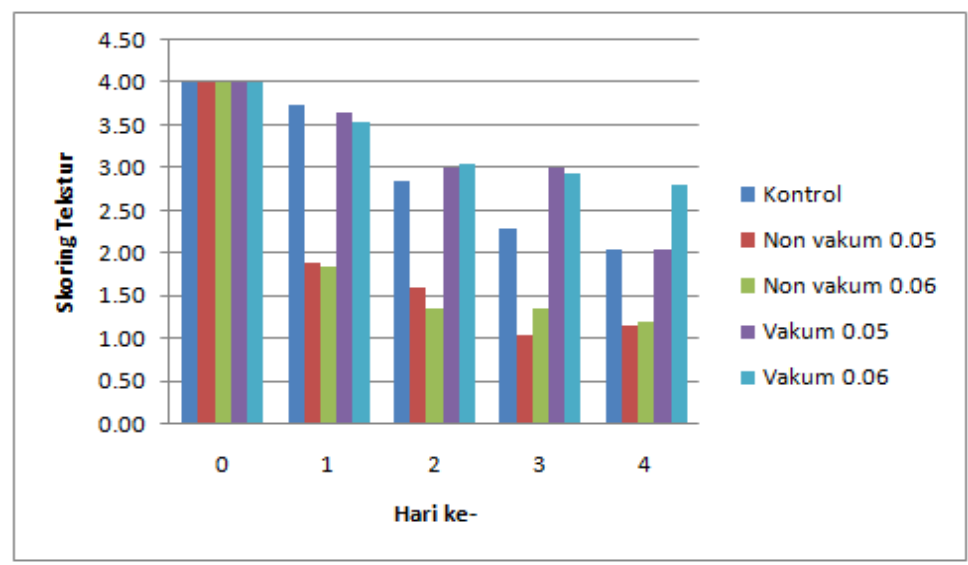

Gambar 3 Penurunan Tekstur Tempe Selama Penyimpanan

Berdasarkan Tabel 3 bahwa tektur tempe selama penyimpanan menunjukkan berbeda nyata terhadap pengemasan vakum dan non vakum kecuali pada hari ke-0, serta tingkat kekerasannya pun turun diseluruh perlakuan.

\section{Penurunan tekstur selama} penyimpanan tempe disebabkan oleh peningkatan kadar air dan proses pembusukan. Kekompakan tempe menjadi lemah karena miselium kapang berkurang bahkan mati, didukung dengan kadar air yang tinggi membuat kedelai menjadi lebih lunak. Menurut Hidayat (2008) menyatakan bahwa tekstur kedelai akan lunak yang disebabkan oleh penurunan selulosa menjadi bentuk yang lebih sederhana yang digunakan hifa kapang sebagai nutrisi dan hifa kapang akan menyelubungi permukaan kedelai yang 
rapat dan kompak serta berbau jamur yang segar. Pada masa pembusukan asam-asam amino dalam kedelai semakin berkurang karena terdegradasi oleh aktivitas enzim proteolitik yang menyebabkan tekstur semakin menurun.

Tekstur tempe semakin lunak seiring masa penyimpanan. Proses pelunakan tempe akibat proses pemanasan disebabkan oleh perubahan sifat fisik dan fungsional dari protein, lemak, pati dan miselium pada tempe. Proses pelunakan pada bahan pangan yang kaya protein dapat disebabkan adanya koagulasi dan kehilangan daya ikat air dari protein. Selain itu dispersi lemak juga dapat menyebabkan tekstur tempe mengalami pelunakan. Proses pelarutan pektin yang ada pada kacang kedelai juga dapat menyebabkan pelunakan tesktur kedelai pada tempe (Suhenri, 2009) dalam (Muslikhah, 2013). Pengaruh pemanasan yang dapat mempengaruhi tekstur tempe dalam penyimpanan tempe ini adanya penyimpanan dengan suhu kamar sekitar $25-30^{\circ} \mathrm{C}$ sehingga mempermudah pelunakan dari tempe tersebut.

\section{Sensoris Aroma Tempe}

Pengujian sensoris dari segi aroma juga menjadi salah satu syarat layak tidaknya suatu produk pangan untuk dikonsumsi. Secara keseluruhan uji aroma ini merupakan bagian termudah dalam mengidentifikasinya, karena tanpa menyetuhnya panelis mampu membedakan bahan pangan yang masih segar dengan yang sudah rusak. Hasil uji sensoris aroma tempe dapat dilihat pada Tabel 4 dan Gambar 4.

Tabel 4 Uji Sensoris Aroma Tempe Selama Penyimpanan

\begin{tabular}{|c|c|c|c|c|c|c|}
\hline \multicolumn{2}{|r|}{ Perlakuan } & \multicolumn{5}{|c|}{ Nilai rata-rata panelis pada hari ke- } \\
\hline Kemasan & Tebal Kemasan (mm) & 0 & 1 & 2 & 3 & 4 \\
\hline \multirow{2}{*}{ Non vakum } & 0.05 & $4.00^{\mathrm{e}}$ & $1.45^{\mathrm{a}}$ & $1.60^{\mathrm{a}}$ & $1.20^{\mathrm{a}}$ & $1.15^{\mathrm{a}}$ \\
\hline & 0.06 & $4.00^{\mathrm{e}}$ & $1.40^{\mathrm{a}}$ & $1.35^{\mathrm{a}}$ & $1.35^{\mathrm{a}}$ & $1.15^{\mathrm{a}}$ \\
\hline \multirow{2}{*}{ Vakum } & 0.05 & $4.00^{\mathrm{e}}$ & $3.45^{\mathrm{e}}$ & $3.00^{c}$ & $2.85^{\mathrm{c}}$ & $2.00^{\mathrm{ab}}$ \\
\hline & 0.06 & $4.00^{\mathrm{e}}$ & $3.45^{\mathrm{e}}$ & $3.00^{c}$ & $3.00^{c}$ & $2.70^{c}$ \\
\hline Kontrol & & $4.00^{\mathrm{e}}$ & $3.65^{\mathrm{e}}$ & $3.00^{\mathrm{c}}$ & $2.00^{\mathrm{ab}}$ & $2.00^{\mathrm{ab}}$ \\
\hline
\end{tabular}

Keterangan : $\quad$ Data diolah menggunakan uji statistik $\alpha=0.05$ dan uji Duncan Skoring : (4) Normal khas tempe; (3) Kurang khas tempe; (2) Bau amonia; (1) Busuk 


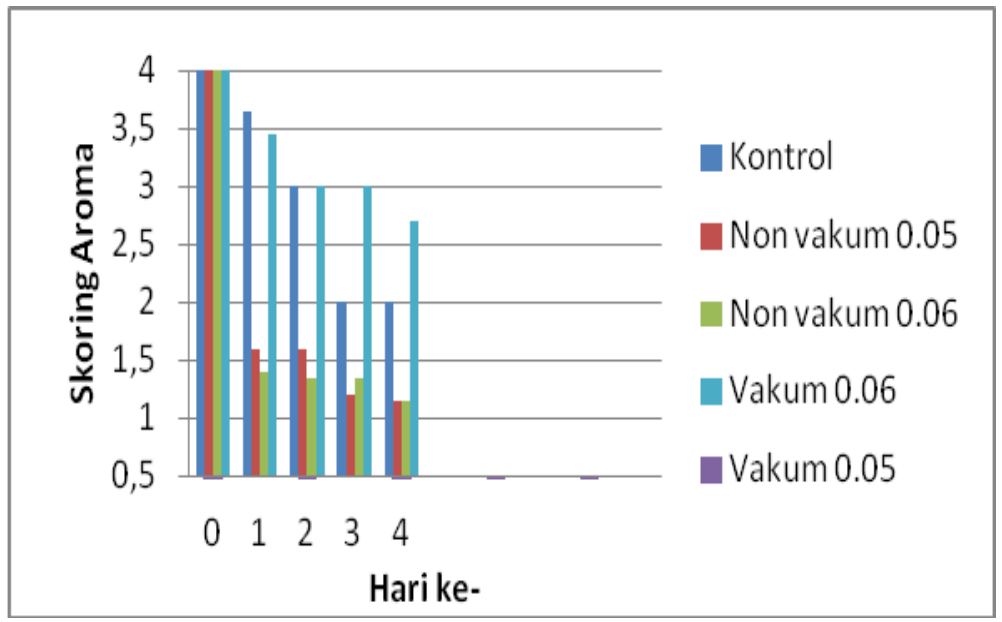

Gambar 4 Penurunan Aroma Tempe Selama Penyimpanan

Pada Tabel 4 bahwa aroma tempe selama penyimpanan menunjukkan berbeda nyata terhadap pengemasan vakum dan non vakum kecuali pada hari ke-0. Trend penurunan kesegaran terlihat dari makin kuatnya bau amonia yang ditimbulkan selama penyimpanan. Bau amonia yang kuat disebabkan oleh proses pembusukan dan akumulasinya yang terjebak di dalam kemasan

Dalam penyimpanan tempe setelah melewati fase transisi, tempe mengalami proses pembusukan. Proses pembusukan terjadi karena mikroorganisme patogen berkembang biak mengubah substrat pada tempe dan mengeluarkan hasil metabolisme bersifat toksin (Puji, 2009). Menurut Ratnawati (2008), mikroorganisme patogen terdapat pada tempe yang sudah rusak antara lain sebagai berikut : (a) Escherichia coli, berperan pada proses asetogenik dengan kondisi aerob dan anaerob fakultatif, ciri- ciri terjadi perubahan kecerahan tempe; (b) Pseudomonas denitrificans dan Micrococcus denitrificans, berperan pada proses pembentukan nitrit dengan kondisi anaerob fakultatif, ciri-ciri tempe berbau amonia ; (c) Leuconostoc mesenteroides, berperan pada proses pembentukan nitrit dan metanogenis, ciri-ciri tempe berbau amonia dan berlendir.

\section{Penentuan Umur Simpan}

Berdasarkan standar SNI 3144 (2009) kadar protein tempe minimal 16\% dan skoring uji sensoris > 2 maka perlakuan terbaik dari keseluruhan parameter penanganan tempe yang menghasilkan umur simpan terlama terdapat pada perlakuan pengemasan vakum dan plastik sekunder PP 0.06, yaitu bertahan selama 4 hari. Penentuan perlakuan terbaik penanganan tempe disajikan pada Tabel 5. 
Tabel 5 Penentuan Perlakuan Terbaik

\begin{tabular}{ccc}
\hline \hline Parameter & Standar/ Skor & Perlakuan \\
\hline Kadar Protein & $\geq 16 \%$ & Vakum 0.05; Vakum 0.06 \\
\hline Warna & $>2$ & Vakum 0.05; Vakum 0.06 \\
\hline Tekstur & $>2$ & Vakum 0.05; Vakum 0.06 ; Kontrol \\
\hline Aroma & $>2$ & Vakum 0.06
\end{tabular}

Keterangan: diperoleh dari pengolahan data kadar protein, warna, tekstur dan aroma menggunakan uji statistik dan Duncan.

\section{KESIMPULAN}

Penurunan kadar protein tempe yang paling lambat dan masih diatas standar SNI (kadar protein tempe minimal $16 \%$ ) yaitu tempe dengan perlakuan vakum dengan kemasan sekunder plastik PP $0.06 \mathrm{~mm}$. Umur simpan dari perlakuan vakum kemasan sekunder plastik PP 0.06 mm maksimal bertahan 4 hari.

\section{DAFTAR PUSTAKA}

Ariyanti, R., 2006, Pembuatan Cookies Dari Tepung Komposit (Kajian Proporsi Tepung: Jagung, Ubi Jalar, Terigu dan Penggunaan Pemanis: Sorbitol, Sukrosa), Jurusan Teknologi Hasil Pertanian Fakultas pertanian Universitas Muhammadiyah Malang, Malang.

Arpah, 2001, Penentuan Kadaluwarsa Produk Pangan, Program Studi Ilmu Pangan Program Pascasarjana IPB, Bogor.

Badan Pusat Statistik, 2010, Hasil Sensus Penduduk 2013, http:// www.bps.go.id

/tab_sub/view.php?tabel=1\& daftar $=1 \&$ id $\_$subyek $=12$, [02 Maret 2017].
Badan Standardisasi Nasional, 2012, Persembahan Indonesia untuk Dunia, BSN2012, Jakarta.

BPOM, 2014, Plastik Sebagai Kemasan Pangan.pdf, http://ik.pom.go.id/v2014 Maret 2017].

Cahyadi, S., 2006, Analisis dan Aspek Kesehatan Bahan Tambahan Pangan, Cetakan Pertama, PT. Bumi Aksara. Jakarta.

Dardanella, D., 2007, Pengaruh Jenis Kemasan dan Kondisi Penyimpanan Terhadap Mutu Produk Keju Cheddar Selama Penyimpanan, htttp://repository.ipb.ac.id/bitstrea $\mathrm{m} /$ handle/ 123456789/11108/F07dda, Februari 2017].

Dwidjosepoetro, D., 1981, Dasar-Dasar Mikrobiologi, Djembatan, Djakarta.

Habibie, M. T., 2014, Kemas Vakum, http://toyibpenyuluh.Blogspot.com /2014/02/kemas-vakum.html Februari 2017].

Harris H. dan Fadli M., 2013, Penentuan Umur Simpan (shelf life) Pundang Seluang (Rasbora sp) Yang Dikemas Menggunakan Kemasan Vakum Dan Tanpa Vakum, 
Fakultas Perikanan Universitas PGRI Palembang, Palembang.

Hidayat, N., 2008, Fermentasi Tempe, http://ptp2007.files.wordpress.com/ 2008 /03/fermentasi-tempe.pdf, [26 Februari 2017].

Muslikhah, S., 2013, Penyimpanan Tempe dengan Metode Modifikasi Atmosfer (Modified Atmosphere) untuk Mempertahankan Kualitas dan Daya Simpan, Fakultas Pertanian Universitas Sebelas Maret, Surakarta.

Puji Astuti, N., 2009, Sifat Organoleptik

Tempe Kedelai, Universitas Muhammadiyah Surakarta, Surakarta.

Ratnawati, L., 2008, Analisis Mutu Gizi Tempe Selama Penyimpanan
Dingin, Akademik Kimia Analisis, Bogor.

SNI.3144, 2009, Syarat Mutu Tempe, Badan Standardisasi Nasional Indonesia, Jakarta.

Sugiarto, 2005, Pengemasan Atmosfer Termodifikasi Bawang Daun ( Alium Ampelopresum) Pajangan, Tesis IPB-Press, Bogor.

Suliantari dan Winiati, P. R., 1990, Teknologi Fermentasi Biji-bijian dan Umbi-umbian., Lembaga Sumberdaya Informasi, Institut Pertanian Bogor, Bogor.

Susiwi, S., 2009, Penentuan Kadaluwarsa Produk Pangan, Jurusan Pendidikan Kimia Fakultas Pendidikan MIPA Universitas Pendidikan Indonesia, Jakarta. 